\title{
Abbreviations Used in Annotation
}

\author{
AHA-American Historical Association \\ DAB-Dictionary of American Biography \\ Ex. Doc.-United States Congress, Senate, Executive Documents, 1st \\ Session, 29th Congress, Senate Document No. 2, Serial No. 480 \\ LC_-Library of Congress, Manuscript Division \\ NA-The National Archives \\ NDA-Navy Department Archives \\ PL_Princeton University Library, Department of Rare Books and \\ Special Collections \\ UT-The University of Texas Library, Archives Collection
}


